\title{
POLITICAL IMPRESSION MANAGEMENT THROUGH DIRECT AND MEDIATED COMMUNICATION: THE 2014/2015 CROATIAN PRESIDENTIAL ELECTIONS
}

\section{Maja ŠIMUNJAK}

Faculty of Arts and Creative Industries, Middlesex University, London Dubravka SINČIĆ ĆORIĆ, Ružica BREČIĆ

Faculty of Economics and Business, Zagreb

UDK: 324(497.5):342.511"2014/2015" 324(497.5):659.4"2014/2015"

Izvorni znanstveni rad

Primljeno: 29. 9. 2016

This paper examines similarities and differences between direct and mediated political candidates' communication during electoral campaigns, and answers the question: How, if at all, do candidates' techniques of impression management differ in their direct and mediated communication. The study is based on content analysis of major daily newspapers, and statements published by candidates in the 2014/2015 Croatian presidential elections on their official Facebook and Twitter accounts. The results show that candidates did not use social media to portray their personal side, humanise their image and create their image of a leader through references to their skills and qualities. Rather, this research shows that in spite of the growing importance of social media, and the willingness and skill of the politicians in employing social media, traditional media, such as newspapers, remain indispensable for providing information about political issues to citizens in this new democracy during presidential elections.

Keywords: social media, traditional media, image, election campaign, presidential elections

$\triangle$ Maja Šimunjak, Faculty of Arts and Creative Industries, Middlesex University, The Burroughs, London NW4 4BT, United Kingdom. E-mail: M.Simunjak@mdx.ac.uk 
It came perhaps as no surprise that Hillary Clinton announced she would run for president in the 2016 US elections on Twitter. Innovative and effective ways in which American President Barack Obama used digital media, and especially social networks, have been widely documented and researched (e.g. Harfoush, 2009; Losh, 2012), and Obama's social media campaigning has been said to have forever changed the way in which American politicians campaign. Whether or not it is a practice imported from the US is a debatable point, but politicians across the world are nowadays seen as engaging with social media.

There appears to be at least two main strands of research on social media in election campaigns. The first one examines politicians' use of social media in campaigns, focusing mostly on the content of the messages, the skills of the politicians in social media communication, and the level of interaction with other actors. Despite the potential for the creative and effective use of social media, studies across the world have found that politicians continue to use social media as a public relations tool for communicating promotional campaign material (e.g. Larsson, 2015; Momoc, 2013; Ross, Fountaine, \& Comrie 2015; Zamora Medina \& Zurutuza Munoz, 2014). Furthermore, if social media is used to communicate information about the candidate, then this is mostly for the purpose of self-promotion as part of the impression management process (Golbeck, Grimes, \& Rogers, 2010; Jackson \& Lilleker, 2011; Stanyer, 2008). The second strand of research looks at the interplay of social media and other mediums during campaigns with a focus on the role of social media campaigning within broader political campaign efforts (e.g. Bode et al., 2016), and the interplay between social and traditional media during election campaigns (e.g. Parmelee, 2014; Conway, Kensky, \& Wan, 2015; Lin, 2016). Studies examining the relationships between social and traditional media in elections mostly focus on intermedia agenda-setting, and findings seem to suggest that there is a 'symbiotic relationship' in place (Conway et al., 2015, p. 363; see also Parmelee, 2014). However, there also seems to be a disparity between how candidates frame impressions on their social media accounts, and how the media reports these (Lin, 2016), although this avenue of research has not yet received adequate scholarly attention.

Our paper seeks to fill this gap in the political marketing and communication literature by unpacking candidates' impression management on social media, and comparing the techniques of impression management employed in social media to those that can be observed from traditional media. 
DRUŠ. ISTRAŽ. ZAGREB GOD. 26 (2017), BR. 4 STR. 539-560

ŠIMUNJAK, M. SINČIĆ ĆÓRIĆ, D. BREČIĆ, R.: POLITICAL IMPRESSION..
Given that previous studies of social media use in campaigning primarily focused on the use of Twitter in established Western democracies, further contributions of this paper are in the examination of Facebook, alongside Twitter, in social media campaigning, and in the analysis of a Central Eastern European democracy, which is an area considerably less researched. Specifically, this paper aims to answer the following research question: How, if at all, did techniques of impression management on social media differ to those that could be observed through mediated communication in the 2014/2015 Croatian presidential elections?

\section{POLITICAL IMPRESSION MANAGEMENT}

De Landtsheer, De Vries, and Vertessen (2008, pp. 220-221) define political impression management as the employment of political marketing techniques with an aim of positioning candidates in the political sphere and persuading voters of candidates' suitability for political office. Previous studies have identified a range of techniques that politicians may employ in order to try to create a favourable impression during election campaigns, such as revealing details from private life (Langer, 2011; Stanyer, 2008), promoting their skills and virtues, attacking opponents (Edelman, 1988; Franklin, 2004) etc. Before the rise of social media, the major focus of research in political impression management was concerned with politicians' attempts to manage their impression via mass media (Campus, 2010; Lin, 2016). With the increasing significance of social media in campaigning, the research focus has shifted to examining how politicians use this direct channel of communication with voters for creating desired impressions. Existing evidence suggests that some politicians have recognised the potential of direct communication with voters and have been using social media to manage their impression, particularly through self-promotion (Stanyer, 2008; Jackson \& Lilleker, 2009, 2011; Svensson, 2012).

Whilst an established model of political impression management does not exist, several authors have outlined techniques that politicians often use for creating desired impressions. In conceptualising a list of techniques that candidates can use on social media to manage impressions, this study draws on strategies outlined by Campus (2010, pp. 222-223), De Landtsheer et al. (2008, pp. 222-228) and Jackson and Lilleker (2011, pp. 89-90). These are: (1) emphasising own skills and virtues, (2) revealing information from private life, (3) attacking political opponents, (4) speaking in colloquial language, and (5) emphasising particular issues. It should be noted that this is not an exhaustive list and that politicians have 
other political impression management techniques at their disposal. However, we deem those five methods mentioned above as the most relevant for the topic discussed in this paper.

\section{Techniques of impression management}

The technique which entails emphasising a candidate's skills and virtues can be seen as forming part of 'packaging politics', which Franklin (2004) describes as a process of constructing and selling politicians in a similar way to cornflakes. This is, of course, quite a negative view on the issue. Others argue that politicians in democracies with a consensus about the main political and societal issues, have to emphasise their skills and qualities in order to differentiate themselves in relation to their opponents. In this context, emphasising one's qualities becomes a brand differentiation technique (Bjerling, 2012; Kuhn, 2004; Šiber, 2003). It is argued that this is an important technique of political impression management on social media, since it allows politicians to present themselves in a positive light, without obstructions by the mass media (Zittel, 2004, p. 232).

Furthermore, disclosing private information, i.e. going personal, is seen as one of the most successful techniques in humanising one's impression in order to portray oneself as 'one of the people' (Grbeša, 2008; Holtz-Bacha, 2004; Langer, 2011). Van Zoonen and Holtz-Bacha (2000, p. 55) stress that 'politicians need to be able to operate smoothly in personal discourse in order to construct themselves as likeable individuals, which is a necessary part of the political persona'. It is believed by many that social media is the place for politicians to disclose their private information and subsequently create personal bonds with voters (Enli \&Skogerbø, 2013; Larsson, 2015; Savulescu \& Vitelar, 2012). It is observed that 'politicians who provide updates on their private life, interspersed with professional and pertinent content, are seen as using social media most effectively' (Hellweg, 2011, p. 30).

Another technique which politicians can employ to portray themselves as close to their voters, is speaking in a colloquial, everyday language (Van Zoonen \& Holtz-Bacha, 2000, pp. 54-55). It is argued that building an impression online should focus on a less fabricated, more natural, personal and 'colloquial' attitude in the communication with the public. Formal communication styles are usually perceived as foreign to social media, and politicians are often criticised for not being able to adapt to social network conventions and communicate in a more informal, relaxed way (Savulescu \& Vitelar, 2012; Zamora Medina \& Zurutuza Munoz, 2014).

Additionally, as Edelman (1988) explains, elections can be seen as a political spectacle in which politicians create them- 
DRUŠ. ISTRAŽ. ZAGREB GOD. 26 (2017), BR. 4 STR. 539-560

ŠIMUNJAK, M. SINČIĆ ĆORIĆ, D., BREČIĆ, R.: POLITICAL IMPRESSION... selves as heroes, for example, by communicating information about their skills, virtues, and accomplishments, and by portraying their opponents as villains. Therefore, by putting the emphasis in their communication on the shortcomings of their opponents, i.e. going negative, politicians may try to influence the impression of their political opponents and position themselves more favourably in the political market. In contrast to previous techniques, going negative may not be a frequently practised technique on social media, particularly on Facebook, which is considered to be a network fostering positive communication and emotions (Carter, 2012, p. 3). Therefore, directly attacking opponents on Facebook might be seen as a misplaced strategy. ${ }^{1}$ Twitter, on the other hand, is known for communicating critical information, and candidates may well try to attack their opponents without having media to frame their statements (Larsson, 2015, p. 462). However, existing research, mostly focused on the US, suggests that Twitter, alongside Facebook, is rarely used by candidates for launching attacks on opponents (Boulianne, 2016; Evans, Cordova, \& Sipole, 2014). Furthermore, even when candidates use Twitter for attacks, tweets promoting positive campaign messages outnumber those negative (Ceron \& d'Adda, 2016, p. 1940). There is some indication that this trend on social media is changing, as counter-trends have emerged during the 2016 US elections (Enli, 2017). Specifically, research suggests that whilst Clinton, in line with previous practice, rarely used Twitter for attacks, Donald Trump extensively used it for launching attacks on other political communication actors (Lee \& Lim, 2016; Ott, 2017).

Finally, Druckman, Jacobs, \& Ostermeier (2004, p. 1183) suggest that candidates can try to manage their impressions by continuous emphasis on particular issues that 'send signals' about their personae. Whilst issue and impression-based campaigning are often seen as distinctive strategies, emphasising particular issues can be seen as contributing to impression management. As Druckman et al. (2004, p. 1184) explain, 'Using issues to prime image in this way resembles issue priming in that candidates invoke discussions of issues; however, the focus is on promoting image rather than on influencing voters' issue preferences'. From the perspective of social media, politicians are able to use social networks to communicate their political viewpoints to their voters in a controlled and unobstructed way. Whilst some argue that this is a great way to communicate political information to citizens, others claim that social networks should be used to supplement a politician's impression by communicating their private persona, rather than repeating the same information from a political sphere (Zamora Medina \& Zurutuza Munoz, 2014, pp. 
DRUŠ. ISTRAŽ. ZAGREB GOD. 26 (2017), BR. 4, STR. 539-560

ŠIMUNJAK, M. SINČIĆ ĆORIĆ, D. BREČIĆ, R.

POLITICAL IMPRESSION..
89-91). Existing research suggests that politicians rarely do either of these two, since they neither use social networks to inform citizens of their policies, nor communicate personal information which would allow voters to get a better understanding of who they 'really' are (Larsson, 2015; Momoc, 2013; Ross et al., 2015). Rather, studies found that politicians often use social media as a public relations tool for relaying information about the campaign, and in that sense, mirror the 'offline', traditional promotional strategies (see also Vergeer, 2015; Zamora Medina \& Zurutuza Munoz, 2014).

\section{Direct and indirect impression management}

The techniques of managing political impressions via social media, as outlined above, can be considered as techniques of direct impression management, since politicians are trying to manage their impression via direct communication with voters. Given that traditional, mass media still play an important role in how voters get information (Lilleker, Tenscher, \& Štětka, 2015; Newman, 2016), the impression that politicians can leave through their mediated statements should not be ignored. However, the research focusing on how politicians manage their impressions through direct and indirect mediated communication is minimal.

Obviously, politicians' statements in traditional media are mediated, i.e. they are filtered, could be taken out of context, presented with journalistic interventions etc. (Lin, 2016, pp. 203-204). By examining what politicians are portrayed as saying in mass media, it is possible to get an insight into the impression that the politician may be seen as trying to create, although the mediated impression may not be what the candidate actually wanted to achieve. For example, the media may be more likely to publish candidates' statements in which they attack opponents, since this kind of rhetoric ties to 'media's preference for negative news' (Pfetsch, 1999, p. 13), as well as their revelations of information from private life, which are seen as particularly newsworthy in media systems with strong commercial elements (Stanyer, 2013, pp. 20-21), as opposed to reinforcing their statements about policies. In this way, the media might create an impression of an offensive candidate who uses their private life for political purposes, while the candidate's communication was actually geared primarily towards other issues.

\section{CROATIAN PRESIDENTIAL ELECTIONS 2014/2015}

Our contextual setting for the research is The Republic of Croatia. Croatia is a parliamentary democracy with dual leadership, since alongside the Prime Minister, the President of the Republic also has some, although very limited, executive pow- 
DRUŠ. ISTRAŽ. ZAGREB GOD. 26 (2017), BR. 4 STR. 539-560

ŠIMUNJAK, M. SINČIĆ ĆORIĆ, D., BREČIĆ, R.: POLITICAL IMPRESSION. ers. The decision to examine the Croatian case has been driven by several factors. Firstly, there is limited research into politicians' impression management in new democracies, and data from Croatia will therefore enrich the existing body of knowledge by demonstrating how political actors can be seen to communicate via traditional and social media in a setting of a new democracy. Moreover, research shows that the use of social networks for political communication, particularly Facebook, is significantly more valued in new as compared to old EU member states (Lilleker et al., 2015, pp. 756-757). Given Croatia is a new member state of the EU, examining the communication of its politicians can assist in establishing techniques of creating public impressions via social networks. Secondly, the electoral system used in the presidential elections is a majority-runoff system, meaning that the voter casts a single vote for the chosen candidate. Consequently, since presidential elections are about electing individuals rather than parties the presidential candidate's impression is one of the most important elements of their campaign. Also, it is more likely that candidates will be inclined to present their personal side, and/or to attack their opponents. Presidential candidates are also likely to try to present themselves as 'one of the people' in order to appear closer to those they wish to represent and to emphasise their qualities and virtues to portray themselves as statesmen/stateswomen, worthy and capable of representing the country abroad. Finally, previous research into Croatian political communication suggests that impression-based campaigning is part of Croatian political culture, and that presidential elections are in general more focused on the candidates than parliamentary elections (Brečić, Milanović, \& Šimunjak, 2012; Grbeša, 2008; Šimunjak, 2012). This is therefore an ideal political climate within which to analyse techniques of political impression management within the social media context.

It should also be noted that Croatia's media system has some elements which contribute and create a fertile ground for politicians' impression-based campaigns. The Croatian media market is liberalised, and the commercialisation of the media system is perhaps most evident in the fact that since 2010, the most watched news and current affairs programme is that of the commercial television station Nova TV (this position was previously held by the public service broadcaster). In addition, the most read daily newspaper since 2006 is 24sata, the only Croatian tabloid (Vozab, 2014, p. 141). Given the reach and importance of commercial and tabloid media, it is likely that politicians will need to employ some or all of the impression management techniques previously described in order to get media coverage during election periods. 
DRUŠ. ISTRAŽ. ZAGREB GOD. 26 (2017), BR. 4, STR. 539-560

ŠIMUNJAK, M., SINČIĆ ĆORIĆ, D. BREČIĆ, R. POLITICAL IMPRESSION..
When it comes to public use of the Internet and social networks, there are 2,104,816 Internet users in Croatia (51\% of total population) (Statistički ljetopis, 2015), and 1,563,000 social network users (36,47\% of total population) (Socialbakers, 2015).

The Presidential elections that are the focus of this paper took place in 2014/2015, and were the sixth presidential elections in Croatia. By way of context, the presidential campaign in 2009/2010 was the first presidential campaign that utilised social media together with traditional media. The two most popular candidates in this election used both Facebook and Twitter, and gained a significant number of followers and fans. The Internet was, for the first time, an equal part of the campaign, together with radio, television and print, although candidates used social media in a significantly lesser scope. This is evident from the quantity of content they posted, as well as from the fact that they stopped using social media the day after the end of the elections. This clearly demonstrates the mere instrumentalisation of the Internet space instead of its use for responsible political communication in previous elections (Zečević, 2015).

\section{RESEARCH DESIGN}

Our research question is answered through the content analysis of candidates' mediated statements in major daily newspapers, and statements which candidates published on their official Facebook and Twitter accounts. ${ }^{2}$ Content analysis was deemed the most suitable method for answering the research question, since it allows researchers to detect trends and patterns in text (Berger, 2011; Deacon, 2007). This is crucial for establishing the type of information published about the candidates, as well as the similarities and differences between their direct and mediated statements. In addition, content analysis has been used in similar previous studies (for an overview see Jungherr, 2014). Although the content analysis does not determine the strategies or intentions of the political actors, or the ways in which the audience/voters have received the information, it remains the most suitable method given this paper's research aims.

The analysis begins by analysing the first day of the official campaign in the 2014/2015 Presidential elections, and ends with the day before the second round of elections, since law prescribes that no campaigning should be done in the period of twenty four hours before the election day. Specifically, the analysis was carried out on statements published from 9 December 2014 to 9 January 2015. Each candidate was followed on Facebook and Twitter and all of his/her posts/tweets were collected. Facebook is included in the analysis since re- 
DRUŠ. ISTRAŽ. ZAGREB GOD. 26 (2017), BR. 4 STR. 539-560

ŠIMUNJAK, M. SINČIĆ ĆORIĆ, D., BREČIĆ, R.: POLITICAL IMPRESSION.. search shows that political actors in new EU member states consider it the most important social network for political communication (Lilleker et al., 2015, pp. 756-757), yet there is little research into its political use. On the other hand, there is an ever-growing body of research into the political communication on Twitter (Jungherr, 2014), and this study aims to contribute to it. The same was done for newspapers, by searching through selected newspapers and collecting all published statements of competing candidates. The decision to use newspapers arises from the fact that their coverage of the election campaigns is not regulated (The Law on the Election of the President of the Republic of Croatia, Article 14), and the material was readily available. The mediated statements were gathered from the most read daily newspapers (excluding the tabloid 24sata) Jutarnji list and Večernji list (Vozab, 2014, p. 141). The unit of analysis is a statement, which is defined as the totality of words within a newspapers article claimed to be said by one of the candidates (direct quote and/or a retold, paraphrased statement) or a social media post that can be identified as having been said/written on a social media profile by a candidate.

Statements by all four presidential candidates were analysed, namely: 1) incumbent Ivo Josipović, the candidate of the governing Social Democratic Party (Socijaldemokratska partija Hrvatske, SDP) and another sixteen parties of the left and centre; 2) main challenger, Kolinda Grabar-Kitarović, the candidate of the right-wing Croatian Democratic Union (Hrvatska Demokratska Zajednica, HDZ) and another seven right-wing parties (Lalić \& Grbeša, 2015, p. 45); 3) young political activist of the Human Wall (Živi zid) Ivan Vilibor Sinčić, often described as an 'anarchist', a political rookie who managed to collect the ten thousand signatures required by law to become a presidential candidate; and 4) right-wing candidate Milan Kujundžić - the candidate of the rigid right-wing coalition led by the Croatian Dawn, The Party of the People (Hrvatska zora - stranka naroda) (Lalić \& Grbeša, 2015, p. 48). Statements made by Sinčić and Kujundžić were analysed only until 28 December 2014 when the first round of elections was held, since these two candidates did not progress into the second round of elections. The final sample consists of 465 statements (see Table 1).

Beyond the variables which aimed to capture the general characteristics of statements (i.e. author of the statement, the medium in which the statement was published), the coding sheet consisted of variables aiming to capture impression management techniques in candidates' statements. The first variable examined the presence of references to skills and virtues, 
DRUŠ. ISTRAŽ. ZAGREB GOD. 26 (2017), BR. 4, STR. 539-560

ŠIMUNJAK, $M$. SINČIĆ ĆÓRIĆ, D. BREČIĆ, R.

POLITICAL IMPRESSION. with an aim to explore the technique of emphasising qualities. The second variable was coded for presence or absence of references to a candidate's private profile. The use of language has been examined through two variables. The first looked at the presence or absence of first person language, while the second aimed to establish presence or absence of colloquial language. Candidates' qualities (skills and virtues), private profile, and colloquial language were defined following previous similar studies (Brečić et al., 2012; Grbeša, 2004). In order to capture the extent to which candidates used attacks as an impression management technique, it was examined whether the candidate attacked anyone in their statement, and who the attack was directed at, by drawing on Brečić et al. (2012, p. 534) and Šimunjak (2012, pp. 41-42). Finally, in order to establish whether candidates emphasised particular issues to manage their impressions, the final variable was coded for the main emphasis of the statement, drawing on a list of issues found to be relevant in previous election studies in Croatia (Brečić et al., 2012; Grbeša, 2004). In instances where the statement referred to several issues at the same time, the dominant issue in the statement was evaluated by coders, and it was therefore coded only for that category. The coding sheet that provides more information about different variables and coding practices is available in the appendix.

The analysis has been carried out by two trained coders. Inter-coder reliability was calculated on a sample of forty five randomly chosen statements ( $10 \%$ of the sample). Average reliability score calculated using Holsti's method of agreement across all categories was 0.91 .

\section{FINDINGS}

The analysis shows that significantly more statements were published via social media than in daily newspapers (see Table 1 ). The incumbent Ivo Josipović was the most active on social networks, whilst the youngest candidate Sinčić, also the only one who, perhaps surprisingly, did not have a Twitter account, published the least statements on social networks. All candidates published statements on social media on average at least once a day, and in the case of the two front-runners, three to six times a day. On the other hand, daily newspapers on average published one to two statements from all candidates each day of the campaign. Given the scarce opportunities to get their messages across via mass media, it appears that social media might have been a useful resource for impression management in these elections. The fact that almost $60 \%$ of social media statements were published on Facebook confirms the findings from Lilleker et al. (2015, pp. 756-757), who found that 
$\rightarrow$ TABLE 1

Number of statements published by candidate for each respective medium
Facebook is considered the most important social network for political communication in the new Member States of the EU, and hence, shouldn't be overlooked in studies of political communication.

\begin{tabular}{lrrrrr}
\hline & Facebook & Twitter & Jutarnji list & Večernji list & Total \\
\hline Grabar-Kitarović & 42 & 47 & 7 & 15 & 111 \\
Josipović & 118 & 76 & 9 & 16 & 219 \\
Sinčić & 42 & 0 & 5 & 9 & 56 \\
Kujundžić & 29 & 37 & 4 & 9 & 79 \\
Total & 231 & 160 & 25 & 49 & 465 \\
\hline
\end{tabular}

In spite of this, our results indicate that the direct involvement of candidates in impression management via social media was much lower than expected. Even though social media impression management activities can be utilised as prolifically as desired by political candidates, the analysis of the techniques of impression management candidates could have been seen as using shows these opportunities have not been exploited by candidates in the $2014 / 2015$ Croatian presidential elections.

\section{Emphasising skills and virtues}

The analysis shows that all the candidates could be seen as emphasising their qualities significantly more frequently in mediated, than in social media statements (see Table 2). To illustrate, Grabar-Kitarović was reported as mentioning her skills and virtues in $64 \%$ of her mediated statements, while she did so in only $19 \%$ of her statements on social networks. A similar discrepancy is visible in all candidates' communication. In addition, all candidates could have been seen as promoting most frequently the same quality i.e. their competence to perform the job of the President. This clearly shows that they did not recognise, or were unwilling to differentiate themselves from competitors by way of their unique virtues and skills, and consequently, to create a distinctive brand (Bjerling, 2012; Kuhn, 2004; Šiber, 2003).

\section{Going personal}

Although information from private life could be interesting to voters, the candidates were in general not willing to allow insights into their private life and interests. This reinforces findings from previous studies of Croatian politicians' communication, which found that they rarely 'go personal' (Brečić et al., 2012; Šimunjak, 2014). Interestingly, all the candidates were reported as revealing details from private lives more frequently in mediated statements, than were mentioned in social 
DRUŠ. ISTRAŽ. ZAGREB GOD. 26 (2017), BR. 4, STR. 539-560

ŠIMUNJAK, M. SINČIIĆ ĆORIĆ, D. BREČIĆ, R.

POLITICAL IMPRESSION..

(1) TABLE 2

Percentage of published statements made by candidates across different mediums with references to skills and virtues; private life; use of first person and colloquial language; and attacking opponents $(n=465)$ media statements (see Table 2). The biggest discrepancy in going personal can be seen in Sinčić's communication. Only $2 \%$ of his social media statements contained reference to his private life, while $29 \%$ of his mediated statements had such a reference.

Despite the fact that social networks thrive on sharing information from the private sphere, the candidates' reticence in applying this technique indicates that the candidates are still not comfortable and/or skilful in presenting private information to boost their political image. Our results suggest that none of the candidates went beyond presenting the formal aspects of their lives, despite the opportunity to do so presented by social media.

\section{Speaking in colloquial and first person language}

Next, attention was directed to the candidates' use of language. The data shows that all the candidates were more frequently reported as communicating in the first person in mediated communication, as opposed to via social networks. This was particularly evident in Grabar-Kitarović's communication, since her sentences often started with 'I will', 'I believe', 'I say', 'I know' etc. Hence, it comes as no surprise that she is quoted as using first person language in 95\% of her mediated statements, but it is surprising that the same type of language was detected in only $28 \%$ of her social media statements. The only candidate who communicated in the first person on social networks was incumbent Josipović (see Table 2 for more details), and even then his use of the first person was limited.

\begin{tabular}{|c|c|c|c|c|c|c|c|}
\hline & & $\mathrm{N}$ & $\begin{array}{r}\text { Skills and } \\
\text { virtues } \\
\%\end{array}$ & $\begin{array}{r}\text { Private } \\
\text { life } \\
\%\end{array}$ & $\begin{array}{r}\text { 1st person } \\
\text { language } \\
\%\end{array}$ & $\begin{array}{r}\text { Colloquial } \\
\text { language } \\
\%\end{array}$ & $\begin{array}{r}\text { Attacking } \\
\text { opponents } \\
\%\end{array}$ \\
\hline \multirow[t]{2}{*}{ Grabar-Kitarović } & Traditional media & 22 & 64 & 14 & 95 & 9 & 55 \\
\hline & Social media & 89 & 19 & 5 & 28 & 2 & 25 \\
\hline \multirow[t]{2}{*}{ Josipović } & Traditional media & 25 & 44 & 8 & 56 & 0 & 48 \\
\hline & Social media & 194 & 14 & 4 & 45 & 8 & 7 \\
\hline \multirow[t]{2}{*}{ Sinčić } & Traditional media & 14 & 43 & 29 & 64 & 7 & 50 \\
\hline & Social media & 42 & 14 & 2 & 5 & 10 & 14 \\
\hline \multirow[t]{3}{*}{ Kujundžić } & Traditional media & 13 & 31 & 15 & 46 & 0 & 31 \\
\hline & Social media & 66 & 3 & 2 & 2 & 17 & 6 \\
\hline & Total & 465 & & & & & \\
\hline
\end{tabular}

Furthermore, the analysis shows that none of the candidates communicated in a relaxed, colloquial tone on social networks. Similarly, this colloquial communication style was not identified in their mediated statements. On one occasion, Sinčić was reported as saying, 'The regime is playing a home 
DRUŠ. ISTRAŽ. ZAGREB GOD. 26 (2017), BR. 4 STR. 539-560

ŠIMUNJAK, M. SINČIĆ ĆÓRIĆ, D. BREČIĆ, R.:

POLITICAL IMPRESSION.. game, their goalpost is 10 centimetres wide and the ball can hardly go in, while my goalpost is from one corner to the next. And as if that's not enough, they also have the judge, the pitch and the delegate.' (Večernji list, 9 December 2014). These findings suggest that candidates failed to portray themselves as 'one of the people' through their use of language, both in traditional and social media.

\section{Attacking opponents}

Candidates were reported as attacking other political actors much more frequently in traditional media than they did on social media (see Table 2). To illustrate, Grabar-Kitarović said: 'Josipović would now want a new beginning. So what was he doing in the past 5 years?' (Jutarnji list, 1 January 2015). Josipović also threw punches, mainly at his main challenger, when saying: 'You were a member of the most corrupt government and you have the least right to criticise' (Jutarnji list, 21 December 2014). The extent to which such attacks took place was significantly lower on social networks. This is in line with previous research which found that going negative is not a commonly employed technique for the social media platform (Boulianne, 2016; Ceron \& d'Adda, 2016; Evans et al., 2014).

\section{Emphasising issues}

The final part of the analysis examined which issues candidates emphasised most frequently in their statements, with the aim of determining whether candidates can be seen as being consistent in emphasising particular issues, and examining how, if at all, this emphasis differed across social media and mediated statements. The data shows that in their mediated statements, all candidates were reported to most frequently emphasise presidential functions and their plans on how to use them once in power. On the other hand, social media seemed to have been used almost exclusively to communicate information about the campaign, its events and developments (Table 3). This suggests that candidates were consistent in emphasising particular topics, which they could have used to promote a desired image (Druckman et al., 2004, p. 1184). It might be speculated from the focus of candidates' mediated statements that they wanted to invoke the discussion of presidential functions and ways in which these would be most efficiently used to promote an image of a forward-thinking and competent statesman/stateswoman. However, social media statements reveal a different story. Given their focus on the campaign, it appears that the social media strategy was focused solely on the promotion of candidates' cam- 
(1) TABLE 3

Focus of candidates' statements presented by medium (TM traditional media, SM - social media) and candidate $(n=465)$ paigns and served as a reminder to their followers of upcoming campaign activities. Consequently, in contrast to mediated statements, it seems that social media has not been recognised or used as a platform for impression management through emphasis on particular issues.

\begin{tabular}{|c|c|c|c|c|c|c|c|c|}
\hline & \multicolumn{2}{|c|}{ Grabar-Kitarović } & \multicolumn{2}{|c|}{ Josipović } & \multicolumn{2}{|c|}{ Sinčić } & \multicolumn{2}{|c|}{ Kujundžić } \\
\hline & TM & $\overline{\mathrm{SM}}$ & $\overline{\mathrm{TM}}$ & $\overline{\mathrm{SM}}$ & $\mathrm{TM}$ & $\overline{\mathrm{SM}}$ & $\mathrm{TM}$ & $\mathrm{SM}$ \\
\hline & $\%$ & $\%$ & $\%$ & $\%$ & $\%$ & $\%$ & $\%$ & $\%$ \\
\hline Socio-political issues & 4 & 5 & 8 & 3 & 14 & 4 & 23 & 6 \\
\hline Campaign & 18 & 62 & 18 & 64 & 0 & 69 & 0 & 80 \\
\hline Elections & 4 & 5 & 12 & 1 & 22 & 5 & 15 & 2 \\
\hline Presidential functions & 50 & 15 & 34 & 26 & 50 & 12 & 39 & 6 \\
\hline Attacks on government & 0 & 1 & 0 & 1 & 14 & 4 & 8 & 2 \\
\hline Attacks on candidates & 16 & 6 & 16 & 4 & 0 & 4 & 15 & 4 \\
\hline Other & 4 & 6 & 4 & 1 & 0 & 2 & 0 & 0 \\
\hline $\mathrm{N}$ (total 465) & 22 & 89 & 25 & 194 & 14 & 42 & 13 & 66 \\
\hline
\end{tabular}

N.B: Only categories that scored above $1 \%$ for at least one candidate are included in the table.

\section{DISCUSSION AND CONCLUSIONS}

The most surprising finding of this research is the fact that politicians' mediated statements were more personalised and negative than direct statements made via social media. Indeed, the results indicate that candidates did not use social media to portray their personal side, to humanise their image and create the impression of being a leader. However, they might appear to be using these same impression management techniques based on the statements published in traditional media.

Given the scope of this study, it is impossible to determine why this happened, but we can speculate about possible scenarios. One way of thinking is to assume that political candidates communicate with voters via social media in a different way, compared to traditional media. This would mean that they are adapting their communication to different audiences and approaching them with diverse goals. It would also point to the fact that politicians' communication for the mass media might be more personal and negative based on the belief that it will result in more coverage in the traditional media.

Another possible scenario that can explain the observed differences is that the media report candidates' personalised and offensive statements more frequently than other types of content because they find them newsworthy. This would mean that the media cherry-picks politicians' statements and can misrepresent their communication strategies by putting more 
DRUŠ. ISTRAŽ. ZAGREB GOD. 26 (2017), BR. 4 STR. 539-560

ŠIMUNJAK, M. SINČIĆ ĆORIĆ, D., BREČIĆ, R. POLITICAL IMPRESSION.. emphasis on one type of statement. In this way, the media can manipulate the impressions of politicians, and voters may see them as going more personal or negative than they actually do.

This has serious implications for those who perceive personalised communication and the creation of political spectacle as detrimental to democratic processes and leading to the trivialisation of political communication (e.g. Franklin, 2004). If it is the traditional media that present politicians as going personal and attacking other actors, then the media, and not political actors, may be culpable for placing the emphasis in political communication on leaders' personalities and political hoopla. In the past, it was frequently claimed that the media were merely reactive and that their focus on politicians instead of parties and programmes has been initiated by the behaviour of politicians (see Campus, 2010; Schulz, Zeh, \& Quiring, 2005; Heath, Jowell, \& Curtice, 1994).

Whatever scenario we choose, the fact remains that the traditional media, which portrayed candidates as going personal and negative in their statements, still reported politicians as mostly communicating about relevant political content, such as their statements about presidential powers and functions, whilst the politicians' direct communication on social media was limited in mentioning socio-political issues, presidential functions, relevance of elections etc. If voters wanted to find out a candidate's thoughts on the function of the president and how they would apply their powers, they were far better off reading candidates' statements in the traditional media than going to their social network sites. So in spite of the growing importance of social media, and politicians' willingness and skill in using social media, traditional media such as newspapers remain indispensable for providing information about political issues to citizens in this new democracy during presidential elections.

Social media, on the other hand, were used neither for communicating relevant political communication, nor for communicating personal information with an aim to create bonds with voters, although it is often emphasised that politicians have an opportunity to use social media for presenting themselves in a personal way, humanising their image and emphasising their virtues (e.g. Larsson, 2015; Savulescu \& Vitelar, 2012). Consequently, our study contributes to the body of data that suggest that political candidates see social media as a public relations vehicle through which they are informing their followers of the campaign events (e.g. Larsson, 2015; Momoc, 2013; Ross et al., 2015; Zamora Medina \& Zurutuza Munoz, 2014). 
DRUŠ. ISTRAŽ. ZAGREB GOD. 26 (2017), BR. 4, STR. $539-560$

ŠIMUNJAK, $M$ SINČIĆ ĆORIĆ, D. BREČIĆ, R.

POLITICAL IMPRESSION.
Given the limitations of the sample and the method, it is not possible to make generalisations beyond the Croatian context, to infer strategy on behalf of political actors, or examine what impressions voters created by consuming information from social and traditional media. However, further research could address these issues to obtain a more holistic view on the process. It would be particularly interesting to examine how voters negotiate impressions about politicians that are based on their direct communication via social networks and those based on mediated statements, given their difference. Furthermore, it would also significantly add to the body of knowledge on the subject to analyse whether voters who get their information primarily via social media have different opinions of political candidates as opposed to those who get their political information primarily via traditional media. Perhaps these issues can be addressed in future research on this topic. Since social media are an evolving platform, we are keen to see how its use will develop over the next presidential elections.

\section{APPENDIX - CODING SHEET}

\section{Unit of analysis: a statement}

A totality of words that a news article claims to be said by one of the candidates (direct quote and/or a retold, paraphrased statement); an individual post/tweet posted on a profile of one of the candidates

1. Who is the author of the statement?

1. Kolinda Grabar-Kitarović

2. Ivo Josipović

3. Ivan Vilibor Sinčić

4. Milan Kujundžić

2. Where was the statement published?

1. Facebook

2. Twitter

3. Jutarnji list

4. Večernji list

Emphasising skills and virtues

3. Which quality does the candidate primarily highlight?

1. No reference to qualities

2. Education

3. Knowledge of international affairs

4. Political experience

5. Competence

6. Charm and charisma

7. Appearance 
DRUŠ. ISTRAŽ. ZAGREB GOD. 26 (2017), BR. 4 STR. 539-560

ŠIMUNJAK, M SINČIĆ ĆORIĆ, D. BREČIĆ, R.: POLITICAL IMPRESSION...
8. Gender (gender identity)
9. Honesty (non corrupted, transparent...)
10. Other

\section{Going personal}

4. Does the candidate refer to his private profile (family, friends, appearance, habits, hobbies, education - from the perspective of a private person)?
1. Yes
2. No

Use of language

5. Does the candidate speak in the first person language (I think, I will, etc.)?

1. Yes

2. No

6. Does the candidate use colloquial language (jargon, humour, irony...)?

1. Yes

2. No

Attacking opponents

7. Who does the candidate attack in the statement?

0 . Nobody

1. Other candidates

2. The government (ruling political party, ministers, the prime minister...)

3. Other political elites (political parties, organisations, politicians...)

4. Others

Emphasising particular issues

8. What is the main issue emphasised in the statement?

1. Current social-political issues (political, economical, affairs...)

2. Campaign (activities, rallies, finances, supports, meetings, slogans...)

3. Elections (participation, Diaspora, democratic process...)

4. Presidential functions (powers, what would they do if they were elected - military, international politics, secret services...)

5. Attacks on the government (government politics, ministers, the prime ministers)

6. Attacks on the opposing candidates

7. Private profile (family, habits, hobbies, fitness, appearance, clothes...) 
DRUŠ. ISTRAŽ. ZAGREB GOD. 26 (2017), BR. 4, STR. 539-560

ŠIMUNJAK, $M$. SINČIĆ ĆÓRIĆ, D. BREČIĆ, R. POLITICAL IMPRESSION..
9. Rebuttal (e.g. It is not true that..., I haven't said..., I have nothing against...)

10. Other

N.B. In instances where the statement refers to several issues, evaluate the dominant issue and code only for that one.

1 In February 2016 Facebook introduced 'Reactions' button, which alongside the 'like' option allows users to express a wider range of reactions to Facebook posts. Arguably, the introduction of the 'sad' and 'angry' options may in the future change Facebook's image of a social network that primarily fosters positive emotions. It should be noted that research for this study was carried out in December 2014 and January 2015, hence before Facebook introduced additional reactions to 'like'.

2 The presented study is part of a larger research investigation into political candidates' communication on social media during the 2014/2015 Croatian presidential elections. The same parameters of the research design are hence apparent in papers reporting other findings from this research project, such as 'Sinčić Ćorić, D., Brečić, R. and Šimunjak, M. (forthcoming) Reaching, engaging and bonding with voters on social media: The case of the 2014/2015 Croatian presidential elections. Medijske studije (Media studies).'

\section{REFERENCES}

Berger, A. A. (2011). Media and communication research methods: An introduction to qualitative and quantitative approaches. London: Sage Publications.

Bjerling, J. (2012). The personalisation of Swedish politics. Party leaders in the election coverage 1979-2010. (Doctoral thesis). University of Gothenberg, Gothenberg.

Bode, L., Lassen, D. S., Kim, Y. M., Shah, D. V., Fowler, E. F., Ridout, T., \& Franz, M. (2016). Coherent campaigns? Campaign broadcast and social messaging. Online Information Review, 40(5), 580-594. https:// doi.org/10.1108/OIR-11-2015-0348

Boulianne, S. (2016). Campaigns and conflict on social media: A literature snapshot. Online Information Review, 40(5), 566-579. https:// doi.org/10.1108/OIR-03-2016-0086

Brečić, K., Milanović, L., \& Šimunjak, M. (2012). Amerikanizacija bez trivijalizacije: Analiza novinskog izvještavanja o predizbornoj kampanji Vesne Pusić 2009. godine [Americanization without trivialization: Analysis of newspaper reporting about Vesna Pusić's 2009 presidential campaign]. Društvena istraživanja, 21(2), 523-244. https://doi.org/ 10.5559/di.21.2.12

Campus, D. (2010). Mediatization and personalization of politics in Italy and France: The cases of Berlusconi and Sarkozy. The International Journal of Press/Politics, 15(2), 219-235. https://doi.org/10.1177/19401 61209358762 
DRUŠ. ISTRAŽ. ZAGREB GOD. 26 (2017), BR. 4 STR. 539-560

\section{ŠIMUNJAK, M. SINČIĆ ĆÓRIĆ, D., BREČIĆ, R.} POLITICAL IMPRESSION..
Carter, B. (2012). The like economy: How businesses are making money with Facebook. Indiana, US: Pearson Education.

Ceron, A., \& d'Adda, G. (2016). E-campaigning on Twitter: The effectiveness of distributive promises and negative campaign in the 2013 Italian election. New Media E Society, 18(9), 1935-1955. https://doi. org/10.1177/1461444815571915

Conway, B. A., Kenski, K., \& Wang, D. (2015). The rise of Twitter in the political campaign: Searching for intermedia agenda-setting effects in the presidential primary. Journal of Computer-Mediated Communication, 20(4), 363-380. https://doi.org/10.1111/jcc4.12124

De Landtsheer, C., De Vries, P., \& Vertessen, D. (2008). Political impression management: How metaphors, sound bites, appearance effectiveness, and personality traits can win elections. Journal of Political Marketing, 7(3-4), 217-238. https://doi.org/10.1080/15377850 802005083

Deacon, D. (2007). Researching communications: A practical guide to methods in media and cultural analysis. London: Hodder Arnold.

Druckman, J. N., Jacobs, L. R., \& Ostermeier, E. (2004). Candidate strategies to prime issues and image. The Journal of Politics, 66(4), 1180-1202. https://doi.org/10.1111/j.0022-3816.2004.00295.x

Edelman, M. (1988). Constructing the political spectacle. Chicago: University of Chicago Press.

Enli, G. (2017). Twitter as arena for the authentic outsider: Exploring the social media campaigns of Trump and Clinton in the 2016 US presidential election. European Journal of Communication, 32(1), 50-61. https://doi.org/10.1177/0267323116682802

Enli, G., \& Skogerbø, E. (2013). Personalized campaigns in party-centred politics. Information, Communication E Society, 16(5), 757-774. https:// doi.org/10.1080/1369118X.2013.782330

Evans, H. K., Cordova, V., \& Sipole, S. (2014). Twitter style: An analysis of how house candidates used Twitter in their 2012 campaigns. PS: Political Science E Politics, 47(2), 454-462. https://doi.org/10.1017/ S1049096514000389

Franklin, B. (2004). Packaging politics: Political communications in Britain's media democracy (Second Ed.). London: Edward Arnold.

Golbeck, J., Grimes, J. M., \& Rogers, A. (2010). Twitter use by the U.S. Congress. Journal of the American Society for Information Science and Technology, 61(8), 1612-1621. https://doi.org/10.1002/asi.21344

Grbeša, M. (2004). Personalization in Croatian presidential election in 2000: How personal did the candidates go and what did the press cover? Politička misao, 41(5), 52-73.

Grbeša, M. (2008). Personality politics in Croatia: An inquiry into election campaigns, media coverage and public perception in the 2003 and 2007 parliamentary elections. (Doctoral dissertation). Faculty of Social Sciences Ljubljana, Ljubljana.

Harfoush, R. (2009). Yes we did: An inside look at how social media built the Obama brand. Berkeley: New Riders.

Heath, A. F., Jowell, R. \& Curtice, J. (1994). Labour's last chance? The 1992 election and beyond. Dartmouth: Aldershot. 
DRUŠ. ISTRAŽ. ZAGREB GOD. 26 (2017), BR. 4, STR. $539-560$

ŠIMUNJAK, M., SINČIĆ ĆORIĆ, D. BREČIĆ, R. POLITICAL IMPRESSION.
Hellweg, A. (2011). Social media sites of politicians influence their perceptions by constituents. The Elon Journal of Undergraduate Research in Communications, 2(1), 22-36.

Holtz-Bacha, C. (2004). Germany: How the private life of politicians got into the media. Parliamentary Affairs, 57(1), 41-52. https://doi.org/ 10.1093/pa/gsh004

Jackson, N. A., \& Lilleker, D. G. (2009). Building an architecture of participation? Political parties and Web 2.0 in Britain. Journal of Information Technology \& Politics, 6(3-4), 232-250. https://doi.org/10.1080/ 19331680903028438

Jackson, N., \& Lilleker, D. (2011). Microblogging, constituency service and impression management: UK MPs and the use of Twitter. The Journal of Legislative Studies, 17(1), 86-105. https://doi.org/10. 1080/13572334.2011.545181

Jungherr, A. (2014). Twitter in politics: A comprehensive literature review. https://doi.org/10.2139/ssrn.2402443

Kuhn, R. (2004). 'Vive la difference'? The mediation of politicians' public images and private lives in France. Parliamentary Affairs, 57(1), 24-40. https://doi.org/10.1093/pa/gsh003

Lalić, D., \& Grbeša, M. (2015). The 2014/2015 Croatian presidential election: Tight and far-reaching victory of the political right. Contemporary Southeastern Europe, 2(1), 45-54.

Langer, A. I. (2011). The personalisation of politics in the UK: Mediated leadership from Attlee to Cameron. Manchester: Manchester University Press.

Larsson, A. O. (2015). Pandering, protesting, engaging. Norwegian party leaders on Facebook during the 2013 'Short campaign'. Information, Communication $\mathcal{E}$ Society, 18(4), 459-473. https://doi.org/10. 1080/1369118X.2014.967269

Lee, J., \& Lim, Y. (2016). Gendered campaign tweets: The cases of Hillary Clinton and Donald Trump. Public Relations Review, 42(5), 849-855. https://doi.org/10.1016/j.pubrev.2016.07.004

Lilleker, D., Tenscher, J., \& Štětka, V. (2015). Towards hypermedia campaigning? Perceptions of new media's importance for campaigning by party strategists in comparative perspective. Information, Communication \& Society, 18(7), 747-765. https://doi.org/10.1080/1369118X. 2014.993679

Lin, L. C. (2016). Convergence in election campaigns: The frame contest between Facebook and mass media. Convergence: The International Journal of Research into New Media Technologies, 22(2), 199-214. https://doi.org/10.1177/1354856514545706

Losh, E. (2012). Channelling Obama: YouTube, Flickr, and the social media president. Comparative American Studies, 10(2-3), 255-268. https:// doi.org/10.1179/1477570012Z.00000000019

Momoc, A. (2013). Social media-PR tools for Romanian politicians? Procedia - Social and Behavioral Sciences, 81, 116-121. https://doi.org/10. 1016/j.sbspro.2013.06.398

Newman, N. (2016). Digital news report 2016. Oxford University. Reuters Institute for the study of journalism. 
DRUŠ. ISTRAŽ. ZAGREB GOD. 26 (2017), BR. 4 STR. 539-560

\section{ŠIMUNJAK, $M$. SINČIĆ ĆÓRIĆ, D. BREČIĆ, R.} POLITICAL IMPRESSION..
Ott, B. (2017). The age of Twitter: Donald J. Trump and the politics of debasement. Critical Studies in Media Communication, 34(1), 59-68. https://doi.org/10.1080/15295036.2016.1266686

Parmelee, J. H. (2014). The agenda-building function of political tweets. New Media \& Society, 16(3), 434-450. https://doi.org/10.1177/14614448 13487955

Pfetsch, B. (1999). Government news management-strategic communication in comparative perspective (No. FS III 99-101). WZB Discussion Paper.

Ross, K., Fountaine, S., \& Comrie, M. (2015). Facing up to Facebook: Politicians, publics and the social media(ted) turn in New Zealand. Media, Culture E Society, 37(2), 251-269. https://doi.org/10.1177/016344 3714557983

Savulescu, R., \& Vitelar, A. (2012). Pics or it didn't happen: Analyzing Facebook photographs of Romanian women politicians. Romanian Journal of Communication and Public Relations, 14(1), 7-20.

Schulz, W., Zeh, R., \& Quiring, O. (2005). Voters in a changing media environment: A data-based retrospective on consequences of media change in Germany. European Journal of Communication, 20(1), 55-88. https://doi.org/10.1177/0267323105047670

Socialbakers statistics (2015). Available at http://www.socialbakers.com/ statistics/facebook/pages/total/croatia/

Stanyer, J. (2008). Elected representatives, online self-presentation and the personal vote: Party, personality and webstyles in the United States and United Kingdom. Information, Communication and Society, 11(3), 414-432. https://doi.org/10.1080/13691180802025681

Stanyer, J. (2013). Intimate politics: Publicity, privacy and the personal lives of politicians in media saturated democracies. Cambridge: Polity.

Statistički ljetopis Republike Hrvatske [Statistical Yearbook of the Republic of Croatia]. Available at http://www.dzs.hr/Hrv_Eng/ljetopis/2014/sljh 2014.pdf

Svensson, J. (2012). Negotiating the political self on social media platforms. Journal of Democracy, 4(2), 183-197.

Šiber, I. (2003). Politički marketing [Political marketing]. Zagreb: Politička kultura.

Šimunjak, M. (2012). The private life as part of Croatian politicians' communication strategies: The 2009-2010 presidential elections. Medijske studije, 3(5), 34-49.

Šimunjak, M. (2014). The (de) personalisation of mediated political communication in communist and post-communist societies: The case of Croatia. (Doctoral thesis). University of East Anglia, Norwich.

The Law on the election of the President of the Republic of Croatia, Article 14. Official Gazette, 22/92, 42/92, 71/97, 69/04, 99/04, 44/06, 24/11, 128/14. Available at http://www.zakon.hr/z/358/Zakon-o-izboru-Pred sjednika-Republike-Hrvatske

Van Zoonen, L., \& Holtz-Bacha, C. (2000). Personalisation in Dutch and German politics: The case of talk show. Javnost - The Public, 7(2), 45-56. https://doi.org/10.1080/13183222.2000.11008743

Vergeer, M. (2015). Twitter and political campaigning. Sociology Compass, 9(9), 745-760. https://doi.org/10.1111/soc4.12294 
DRUŠ. ISTRAŽ. ZAGREB GOD. 26 (2017), BR. 4, STR. $539-560$

ŠIMUNJAK, M., SINČIĆ ĆÓRIĆ, D. BREČIĆ, R. POLITICAL IMPRESSION.
Vozab, D. (2014). Tisak u krizi: analiza trendova u Hrvatskoj od 2008. do 2013. [Press in crisis: Analysis of trends in Croatia from 2008 to 2013.] Medijske studije, 5(10), 139-147.

Zamora Medina, R., \& Zurutuza Munoz, C. (2014). Campaigning on Twitter: Towards the 'personal style' campaign to activate the political engagement during the 2011 Spanish general elections. Communication \& Society, 27(1), 83-106.

Zečević, A. (2015, May 19). Intervju s Perom Maldinijem: "U Hrvatskoj je još jako podaničko političko naslijeđe" [Interview with Pero Maldini: "The subject-ruler political legacy is still strong in Croatia"]. Nacional, 889. Available at http://www.nacional.hr/intervju-s-perommaldinijem-u-hrvatskoj-je-jos-jako-podanicko-politicko-naslijede/

Zittel, T. (2004). Political communication and electronic democracy: American exceptionalism or global trend? In F. Esser \& B. Pfetsch (Eds.), Comparing political communication: Theories, cases, and challenges (pp. 231-250). Cambridge: Cambridge University Press. https://doi.org/ 10.1017/СBO9780511606991.011

\section{Upravljanje političkim imidžom kroz direktnu i medijatiziranu komunikaciju: Hrvatski predsjednički izbori 2014./2015.}

Maja ŠIMUNJAK

Fakultet umjetnosti i kreativnih industrija, Middlesex University, London

Dubravka SINČIĆ ĆORIĆ, Ružica BREČIĆ

Ekonomski fakultet, Zagreb

Cili je ovoga rada istražiti što se o kreiranju vlastita imidža može iščitati iz javne komunikacije političkih aktera te postoje li u ovom kontekstu razlike između političarove komunikacije u medijima i one s društvenih mreža. Istraživanje je provedeno analizom sadržaja izjava u medijima predsjedničkih kandidata $u$ izborima za hrvatskoga predsjednika 2015./2016. godine te analizom izjava koje su ti kandidati objavili na svojim društvenim mrežama. Rezultati pokazuju da kandidati nisu rabili društvene mreže za razmienu privatnih informacija, humanizaciju imidža i kreiranje imidža vođe. Naprotiv, analiza pokazuje da unatoč rastu važnosti društvenih mreža te volii i vještini političara u nïhovoj upotrebi, tradicionalni mediii, poput dnevnih novina, ostaju jedan od ključnih kanala kojima se birači mogu informirati o političkim procesima tijekom predsjedničkih izbora.

Ključne riječi: društvene mreže, tradicionalni mediii, imidž, izborna kampanja, predsjednički izbori

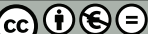

Međunarodna licenca / International License:

Creative Commons Attribution-NonCommercial-NoDerivatives 4.0. 